Article

\title{
Excavation Method Determination of Earth-Retaining Wall for Sustainable Environment and Economy: Life Cycle Assessment Based on Construction Cases in Korea
}

\author{
Youngman Seol ${ }^{1}$, Seungjoo Lee ${ }^{2}$, Jong-Young Lee ${ }^{3}\left(\mathbb{D}\right.$, Jung-Geun Han ${ }^{3,4}{ }^{*}$ and Gigwon Hong ${ }^{5, *}$ \\ 1 Department of Civil Engineering, Chung-Ang University, 84 Heukseok-Ro, Dongjak-gu, Seoul 06974, Korea; \\ great@kecgroup.kr \\ 2 NEO-TRANS Co., Ltd., 33 Daewangpangyo-Ro, 606 Beon-Gil, Bundang-Gu, Seongnam-Si, \\ Gyeonggi-do 13524, Korea; seunglee@doosan.com \\ 3 School of Civil and Environmental Engineering, Urban Design and Studies, Chung-Ang University, \\ 84 Heukseok-Ro, Dongjak-gu, Seoul 06974, Korea; geoljy@cau.ac.kr \\ 4 Department of Intelligent Energy and Industry, Chung-Ang University, 84 Heukseok-Ro, Dongjak-gu, \\ Seoul 06974, Korea \\ 5 Department of Civil and Disaster Prevention Engineering, Halla University, 28 Halladae-gil, Wonju-si, \\ Gangwon-do 26404, Korea \\ * Correspondence: jghan@cau.ac.kr (J.-G.H.); g.hong@halla.ac.kr (G.H.)
}

check for

updates

Citation: Seol, Y.; Lee, S.; Lee, J.-Y.; Han, J.-G.; Hong, G. Excavation

Method Determination of

Earth-Retaining Wall for Sustainable

Environment and Economy: Life

Cycle Assessment Based on

Construction Cases in Korea.

Sustainability 2021, 13, 2974.

https://doi.org/10.3390/su13052974

Academic Editor: Sunkuk Kim

Received: 21 January 2021

Accepted: 5 March 2021

Published: 9 March 2021

Publisher's Note: MDPI stays neutral with regard to jurisdictional claims in published maps and institutional affiliations.

Copyright: (C) 2021 by the authors. Licensee MDPI, Basel, Switzerland. This article is an open access article distributed under the terms and conditions of the Creative Commons Attribution (CC BY) license (https:// creativecommons.org/licenses/by/ $4.0 /)$.
Abstract: This study describes life cycle assessment (LCA) results of the excavation depth and ground condition of a medium-sized excavation ground in order to examine the effect of construction methods on environmental and economic feasibility for an earth-retaining wall. LCA is conducted in consideration of eight environmental impact categories according to the construction stage of the earth-retaining wall. In addition, the environmental cost of construction method for the earthretaining wall was calculated, and its selection criteria were analyzed based on the calculation results. The evaluation results of the environmental load of construction methods for the earth-retaining wall show that the H-Pile+Earth plate construction method has low economic efficiency because the construction method significantly increased the environmental load due to the increased ecological toxicity. The environmental load characteristics have a greater effect on the selection of construction methods in sandy soil than in composite soil when the excavation depth is the same. The evaluation result of the environmental cost of the construction methods for the earth-retaining wall shows that the environmental cost increased as the excavation depth increased, and the sandy soil conditions have higher environmental costs than complex soil conditions.

Keywords: LCA (life cycle assessment); earth-retaining wall; excavation; environment load; environment cost

\section{Introduction}

LCA, called life cycle assessment or life cycle environmental load assessment, is defined as a technique that identifies life cycle flows, such as raw material and energy input, pollutant occurrence, and recycling in product production, and it assesses potential environmental impacts. That is, it is an evaluation of the environmental impact of the entire process of obtaining raw materials for products, production, application, and disuse, i.e., the entire process from the acquisition of raw materials to the final disposal of the product [1-3] LCA, an environmental evaluation technique, is actively used as a technology evaluation method to secure source technologies to respond to climate change worldwide. [4-8]. LCA is not limited to assessing greenhouse gas emissions, but they are focused on in the literature review section of this study, because Korea is facing the considerable issue of greenhouse gas emissions in the field of construction.

Large-scale facilities are planned mainly in the construction industry. The application of LCA in this field can sufficiently consider the environmental impact, because there are 
many types and quantities of materials, and high-energy facilities are applied. In particular, rapid decision support is possible for environmental issues if LCA is performed in the early stages of a project $[9,10]$. As a result of forecasting greenhouse gas emissions by the industry sector by 2030, Lee [11] predicted that emissions associated with the construction industry will increase by $2.2 \%$ by 2030 . In 2015, the International Energy Agency (IEA) established a plan to induce and support greenhouse gas reduction activities with the aim of implementing greenhouse gas target management in the construction industry; in Korea, $8.34 \%$ and $2.07 \%$ reduction targets were established in the building and transportation sectors, respectively. As mentioned above, various studies on environmental impact assessment of greenhouse gases emitted from construction activities have been actively conducted in order to respond to the international situation [12-14].

The Korean construction market is expanding not only to the infrastructure sector but also to the energy and building sectors, mainly in the carbon emission rights market, renewable energy market, and green building market, so it is time to require a more aggressive response and greater investment. Overseas, it is reported that Europe classifies the construction industry as one of the seven major sectors that emit greenhouse gases, and the construction industry accounts for $36 \%$ of total industrial carbon emissions and $40 \%$ of total energy consumption. It was determined that the cause of these results is closely related to the fuel use of construction equipment and gas emissions due to various construction activities, and studies have been conducted to contribute to reducing the emission of greenhouse gases [15-17].

Research on LCA has actively been carried out abroad for more than two decades. Europe is a leader in the field of LCA research, and many studies have been conducted on methodology, life cycle inventory (LCI) DB (Database) construction, and program development in the field of the environment [18]. Japan is attempting a systematic approach to LCA, and Australia has constructed an LCI DB mainly of infrastructure facilities, such as buildings, raw materials, iron, minerals, and packaging materials. In addition, various case studies have been conducted to evaluate the environmental impact related to greenhouse gases on the foundation work of buildings and residential buildings [19-22]. Moreover, in many advanced countries, evaluation programs that take into account the life cycle of construction materials have been developed and put into use, and they have been set as sustainable development goals to reduce the environmental load in the construction industry [23-25]. Recently, research on LCA has been conducted in various environmental fields in Korea. It has been only 5 years since the study on the field of civil engineering took off in Korea, so the available data related to construction materials and construction are insufficient. Additionally, LCA is partly applied to SOC (social overhead capital) facilities, such as roads, bridges, and tunnels, in which the target facilities are standardized [26,27].

Therefore, this study aims to improve the process by which existing construction methods are selected by additionally applying the results of LCA analysis, such as constructability and economic feasibility, to the way a construction method is selected when considering various soil conditions. To this end, the earth-retaining wall, a representative soil structure, was selected as the target structure, and a case of securing stability through a series of design processes was established for various excavation conditions and construction methods after simplifying the excavation-related ground conditions. Afterward, the environmental loads for the eight major categories in the environmental product declaration (EPD), such as greenhouse gas emissions and energy consumption, which are the main management targets of the Greenhouse Gas and Energy Target Management System, were analyzed and applied to the established case. Based on this analysis, in order to minimize the environmental load when selecting a construction method for an earth-retaining wall, LCA analysis for an earth-retaining wall according to excavation depth and soil conditions was conducted to prepare improvement measures. 


\section{Theoretical Review of LCA Technique}

\subsection{Concept of LCA Technique}

LCA, also called "life cycle environmental load assessment," is a technique to identify the inputs of raw materials, energy, chemicals, etc. and outputs of wastes, pollutants, recycling, etc. in the life cycle of a product and to evaluate potential environmental impacts (Figure 1).

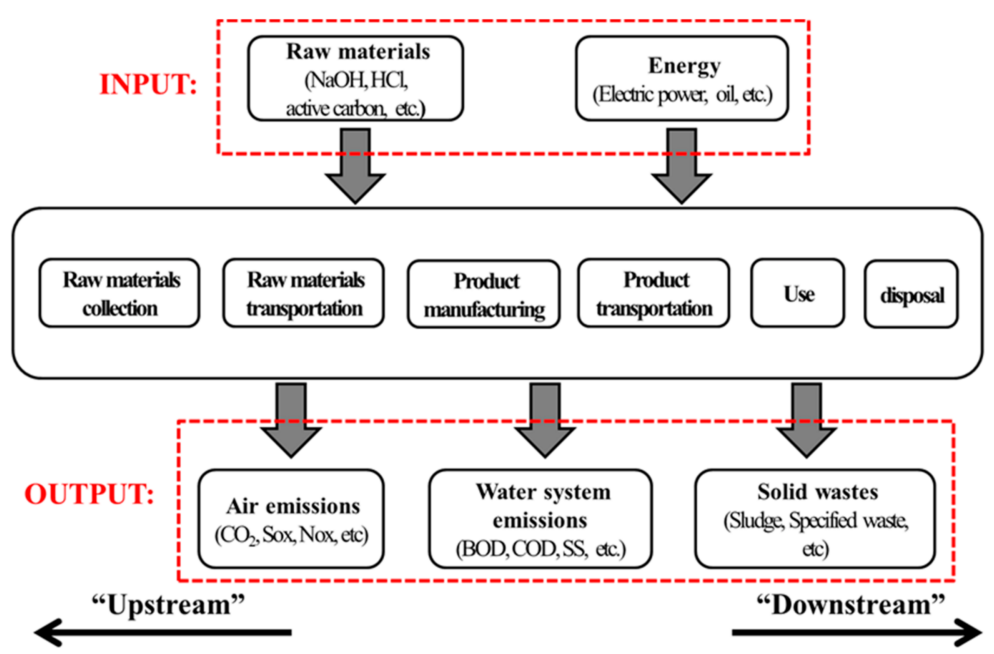

Figure 1. Overall process and input/output of life cycle assessment (LCA).

Raw materials, energy, and utilities are inputs, and air emissions, water system emissions, solid wastes, etc. in the manufacturing process, the use process, and the disposal process are outputs. Early stages of the construction process such as collection and transportation of raw materials are referred to as "upstream," whereas product use and disposal are "downstream."

General guidelines to LCA structures and procedures used to assess environmental performance in a series of processes can be found in ISO standards 14040 and 14044, international standards for environmental management (green management) established by the International Organization for Standardization (ISO) [1,2]. As shown in Figure 2, the LCA consists largely of objectives and scope definitions, inventory analysis (LCI), impact assessment (LCA), and interpretation of results.

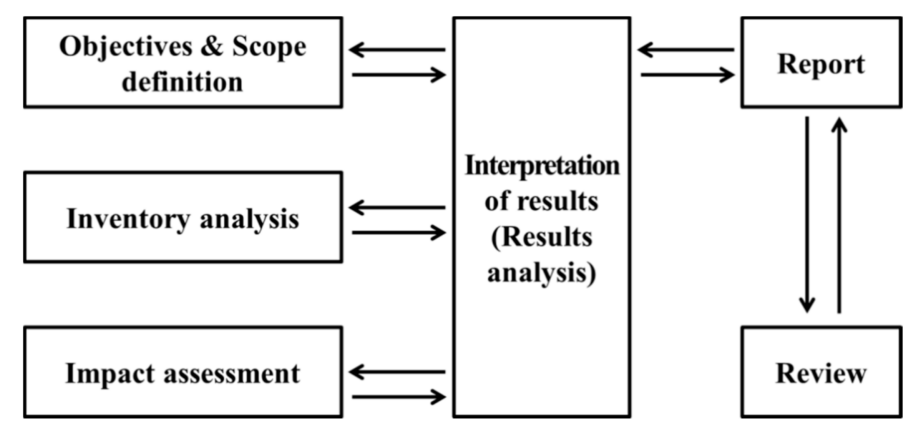

Figure 2. Procedure of life cycle assessment (LCA).

LCA is used to provide a scientific basis for determining which of several processes has a significant environmental impact or which of several products is environmentally friendly. For instance, LCA can be performed to identify which construction method, A or $\mathrm{B}$, has a smaller impact on the environment. This process makes quantitative numerical comparisons possible by collecting data on materials and equipment that are inputted during the construction and maintenance stages of a comparative construction method 
and by setting inputted material, energy, and resource usage units. LCA has recently been applied to the construction industry internationally to reflect various environmental impact assessments in the planning and design stages, making it possible to design alternatives by taking into account the environmental friendliness, such as the comparison of routes and construction methods. Therefore, as it is necessary to introduce and effectively apply decision-making methods for environmentally friendly development in the construction sector, the LCA, in which environmental performance in terms of construction environment and environmental value through the quantification of environmental load are evaluated, is a significant factor.

\subsection{Application of LCA in the Construction Industry}

Although there have not yet been many cases in which an LCA evaluation was conducted in Korea, the results of analyzing various cases performed concerning roads/bridges, ports, and railways are as follows: First, the evaluation method was conducted by analyzing material and equipment inputs through information collection and analysis and then evaluating environmental and economic feasibility by calculating the environmental load through LCA evaluation by comparison. In addition, LCA analysis as a comparison method is performed in the application stage of a construction method, and LCA analysis of the basic plan and basic design is conducted after dividing it into the initial construction stage, maintenance stage, and dismantling and disposal stage. In other words, in life cycle cost (LCC) analysis as a comparison method, the environmental loads for eight environmental impact categories (abiotic resource depletion, global warming, ozone depletion, photochemical oxidant creation, acidification, eutrophication, ecotoxicity, and human toxicity) are calculated, and those for key contributors to global warming (carbon dioxide $\left(\mathrm{CO}_{2}\right)$, sulfur dioxide $\left(\mathrm{SO}_{2}\right)$, nitrogen dioxide $\left(\mathrm{NO}_{2}\right)$, and carbon monoxide $(\mathrm{CO})$ ) out of all environmental impact categories are calculated and compared to alternatives. After analyzing the effect on the reduction of environmental load of the basic design, reflecting the final LCA evaluation results, with the reduced values of the environmental indices compared to the basic plan, the basic design was presented, which makes environmental economic feasibility or environmentally friendly design possible.

Meanwhile, more work is being done in foreign countries. The Netherlands has been developing LCA evaluation programs for the construction industry since 1994, with work being conducted by major construction-related organizations (e.g., the Ministry of Housing, Spatial Planning, and Environmental), with various types of data now being provided, such as the reliability of LCA. In Finland, LCA of the construction industry is conducted by the VTT Technical Research Centre of Finland; the scope of the LCA is set at each life cycle stage of an individual building, such as material production, transportation, construction, maintenance, and dismantling, and the environmental impact data obtained from these results are used in marketing, product display, system management, and product design [28]. Recently, Han et al. [29] developed a tool that considers cost and environmental impact together by utilizing building information modeling (BIM) based on information and communication technologies (ICTs) to link LCC throughout the life cycle of a building to LCA tools. In order to develop a database that can reflect greenhouse gas reduction, Japan developed an environmental load inventory for individual items by utilizing a method to correct the estimates with inter-industry relational tables based on the detailed DB calculated using the estimation method. By making use of these methods, the environmental load of new materials such as eco-cement to consider the environment can be updated from time to time through the $\mathrm{DB}$, and a basis for conducting evaluations that reflect an environmental load of materials has been prepared. The American Society for Testing and Materials (ASTM) in the United States prepares guidelines for LCA of construction materials, design of green buildings, construction, and operation, and the National Institute of Standards and Technology (NIST) develops Building for Environmental and Economic Sustainability (BEES) to support the selection of economic and environmentally friendly construction materials. 
As mentioned above, mainly overseas, evaluation software that considers all aspects of construction materials has been developed and utilized mainly in the construction sector, and various activities have been carried out to reduce the environmental pollution load in the construction sector with the goal of sustainable development. Table 1 shows these research activities by country.

Table 1. Life cycle assessment (LCA) application status by country (Kwon [30]).

\begin{tabular}{|c|c|c|c|}
\hline Country & Purpose & Project Contents & $\begin{array}{c}\text { Research } \\
\text { (Managing) Institute }\end{array}$ \\
\hline The United States & $\begin{array}{l}\text { Decision support for purchasing } \\
\text { construction materials with } \\
\text { excellent environmental } \\
\text { economic feasibility. } \\
\text { Developed as part of the US } \\
\text { EPA (Environmental Protection } \\
\text { Agency) Green } \\
\text { Purchasing Program. }\end{array}$ & $\begin{array}{l}\text { Standardize both the LCA as an } \\
\text { environmental performance } \\
\text { evaluation tool and the LCC as an } \\
\text { economic feasibility evaluation } \\
\text { tools into ASTM (American } \\
\text { Society for Testing and Materials). } \\
\text { Development of a methodology } \\
\text { and software called BEES } \\
\text { (Building for Environmental and } \\
\text { Economic Sustainability) to } \\
\text { integrate and make a decision. }\end{array}$ & $\begin{array}{c}\text { NIST (National Institute of } \\
\text { Standards and Technology) of } \\
\text { the United States }\end{array}$ \\
\hline Finland & $\begin{array}{l}\text { Finding ways to convert } \\
\text { construction materials, } \\
\text { construction, and construction } \\
\text { waste treatment in civil } \\
\text { infrastructure projects such as } \\
\text { road construction in an } \\
\text { environmentally } \\
\text { friendly manner. }\end{array}$ & $\begin{array}{c}\text { LCI DB (Life Cycle Inventory } \\
\text { DataBase) construction for } \\
\text { construction industry. } \\
\text { LCA implementation for various } \\
\text { construction scenarios. } \\
\text { Comparative evaluation } \\
\text { by scenario. }\end{array}$ & $\begin{array}{c}\text { Road Corporation } \\
\text { VTT }\end{array}$ \\
\hline Sweden & $\begin{array}{l}\text { Identifying the significance of } \\
\text { road maintenance from an } \\
\text { LCA perspective. }\end{array}$ & $\begin{array}{l}\text { Identification of environmental } \\
\text { impacts throughout the entire } \\
\text { process of road construction, } \\
\text { maintenance, and disposal, and } \\
\text { support of various } \\
\text { decision-making processes. }\end{array}$ & $\begin{array}{l}\text { Road Corporation } \\
\text { IVL }\end{array}$ \\
\hline Netherlands & $\begin{array}{l}\text { Identifying environmental } \\
\text { impacts on national } \\
\text { infrastructure industries, such } \\
\text { as sewage facilities, through } \\
\text { LCA techniques. }\end{array}$ & $\begin{array}{l}\text { Identifying environmental } \\
\text { performance through LCA } \\
\text { techniques in constructing } \\
\text { various national infrastructures. } \\
\text { Support for environmentally } \\
\text { friendly design. }\end{array}$ & $\begin{array}{c}\text { Concrete Association } \\
\text { Cement Association } \\
\text { INTRON } \\
\text { BRE }\end{array}$ \\
\hline England & $\begin{array}{l}\text { Building material } \\
\text { certification program }\end{array}$ & $\begin{array}{l}\text { Quantifying the environmental } \\
\text { performance of construction } \\
\text { materials using LCA techniques. }\end{array}$ & BRE certification authority \\
\hline Australia & $\begin{array}{c}\text { Transitioning to an } \\
\text { environmentally friendly } \\
\text { construction industry using } \\
\text { LCA technique. }\end{array}$ & $\begin{array}{l}\text { Identifying opportunities for } \\
\text { environmental improvement for } \\
\text { construction materials and } \\
\text { systems through } \\
\text { performing LCA. }\end{array}$ & $\begin{array}{l}\text { Ministry of Environment } \\
\text { RMIT (Royal Melbourne } \\
\text { Institute of Technology) }\end{array}$ \\
\hline Japan & $\begin{array}{l}\text { Increasing the Recycling Rate of } \\
\text { Construction Waste. }\end{array}$ & $\begin{array}{l}\text { Identification of carbon dioxide } \\
\left(\mathrm{CO}_{2}\right) \text { throughout the entire } \\
\text { process of the } \\
\text { construction industry }\end{array}$ & $\begin{array}{l}\text { KAJIMA Construction } \\
\text { Company }\end{array}$ \\
\hline
\end{tabular}




\subsection{Application of Similar Techniques for the Selection of Construction Methods on Civil Engineering Structures}

Bae [31] suggested a system for selection of construction method by classifying influential factors by applying the analytical hierarchy process (AHP) technique to the selection of construction methods for an underground retaining wall; Han and Lee [32] applied the AHP technique to work conducted by a group of experts in related fields when selecting the reinforcing method for a cut slope. Lee et al. [33] once presented a decision model for selecting soft ground improvement methods using AHP techniques, and Lee and Jeong [34] proposed a decision-making system using the AHP technique and preference function (PF) when selecting the basic construction method for structures.

In order to resolve the inaccuracies intrinsic to the subjective judging process and reduce the uncertainty and ambiguity of the AHP method in bridge construction projects, Pan [35] proposed the fuzzy AHP (FAHP) model by applying triangular and trapezoidal fuzzy numbers and the $\alpha$-cut concept. Ebrahimian et al. [36] pointed out that application of the existing AHP technique has the drawback that the pairwise comparison required for hierarchy analysis is tedious and time-consuming in the planning phase of a construction project when complex interests are concerned, such as urban construction projects, and suggested a combined model of fuzzy AHP (FAHP) and compromise programming (CP).

Shen et al. [37] introduced text mining case-based reasoning (TM-CBR), which can extract the most similar case from a design by integrating the text mining technique into the CRB system in order to improve the efficiency of decision-making in environmentally friendly design. Lorenz and Jost [38] reported that the system dynamic model is an efficient way to select the best method for a given purpose; Tsai et al. [39] proposed the multiple criteria decision making (MCDM) approach to resolve the impact on the goal of the time, cost and environmental Impacts (TCEI) analysis, the selective issue on how decision-makers determine the most appropriate construction methods.

In order to rationalize selection of construction methods for a retaining wall, Kim et al. [40] used a neural network system to verify the rationality of the selection at approximately 160 sites and showed predictive results of $88 \%$ in the selection of a construction method and $90 \%$ in the selection of the wall retaining method. Furthermore, the selection of the construction method for a retaining wall has many factors to consider and is based on uncertain information, resulting in frequent design changes and consequent delays in construction and lots of economic loss. To overcome this issue, we highlight the limitation that artificial intelligence (AI) technology is limited to new projects even though it can be used to support complex decision-making processes [40,41]; when selecting tunnel construction methods, Park et al. [42] applied the AHP technique to the existing problems of value engineering (VE), and LCC and proposed the life cycle social cost (LCSC) evaluation method to convert social loss expenditures, which could not be applied in the LCC technique.

However, as mentioned above, in most previous research, several decision-making methods have been adopted to rationally select the construction method for an earthretaining wall, and most of them suggested only the applicability and rationality of appropriately applied construction methods based on the existing application cases.

That is, in order to select a rational construction method, an evaluation system that considers social loss expenses (environmental factors) and social factors has been used only with improvements. Therefore, there is a limit to using the mechanical relationship among construction methods, soil, material, and environment based on a stability-based design for various soil conditions when selecting construction methods for an existing earth-retaining wall.

Therefore, beyond the selection of a construction method that focuses on the given soil conditions and the usability and stability of the materials in each construction method, a study is needed that addresses how to select a construction method for earth-retaining walls that considers economic feasibility and environmental performance applied the conversion of environmental costs as well as LCA analysis considering environmental performance in the existing method. 


\section{Selection of Cases and Stability Review for LCA of Earth-Retaining Wall \\ 3.1. Evaluation of Case Selection and Soil Characteristics}

In this section, we set the selection criteria with which the construction method for a retaining wall is applied and propose a resultant rational selection method. In this study, rational selection methods are classified by taking excavation size and excavation depth into account based on the "Special Law about Underground Safety Management (2018)" and "Review Guideline on Excavation for Safe Building Construction" of Seoul Metropolitan City, created for special safety management considering the stability of recent ground subsidence. The criterion for excavation depth under the Special Law about Underground Safety Management is $20 \mathrm{~m}$, and the criterion for excavation depth of buildings under architectural design-review in urban areas is $10 \mathrm{~m}$. Therefore, as shown in Table 2, the excavation depth at which the earth-retaining wall was installed was $15 \mathrm{~m}$, the middle value of the two standards. This can be viewed as a criterion considering the fact that various construction methods use a $15 \mathrm{~m}$ excavation depth. Additionally, the characteristics of the soil to be installed are mostly distributed from the surface to the topsoil, weathered soil, weathered rock, soft rock, and hard rock, in that order, and the weathered soil is mostly composed of deposits. There is also a composition of the sandy soil layer and soft clay layer on the rock layer of a riverbank or shoreline, and, most commonly, it is to consist of composite stratum (typically weathered soil layers) on the rock layer. Thus, the new construction method can be applied if it is composed of only rock layers, so the general sediment layer consists of the sandy soil layer, soft clay layer (soft clay ground), and the mixed stratum of the sandy soil and soft clay. Therefore, we decided to conduct an analysis based on these soil compositions in this study (Table 3). The applied equipment and the construction management method are different according to the excavation scale and ground conditions in excavation construction. Thus, the excavation scale and the ground conditions were applied as comparative criteria in this study.

Table 2. Excavation conditions and soil conditions in each case.

\begin{tabular}{|c|c|c|c|c|}
\hline No & $\begin{array}{l}\text { Excavation } \\
\text { Area } \\
\left(\mathrm{m}^{2}\right)\end{array}$ & $\begin{array}{l}\text { Excavation } \\
\text { Depth } \\
(\mathrm{m})\end{array}$ & $\begin{array}{l}\text { Soil } \\
\text { Conditions }\end{array}$ & $\begin{array}{c}\text { Construction Method for } \\
\text { Earth } \\
\text { Retaining Wall }\end{array}$ \\
\hline Case 01 & \multirow{18}{*}{$\begin{array}{c}50 \mathrm{~m} \times 50 \mathrm{~m} \\
\text { (Medium-Scale) }\end{array}$} & \multirow{10}{*}{$\begin{array}{c}15 \\
\text { (Shallow Excavation) }\end{array}$} & \multirow{4}{*}{ Composite Soil } & C.I.P (Cast-In-Placed pile) \\
\hline Case 02 & & & & S.C.W (Soil Cement Wall) \\
\hline Case 03 & & & & Sheet Pile \\
\hline Case 04 & & & & H-Pile+Earth Plate \\
\hline Case 05 & & & & C.I.P (Cast-In-Placed pile) \\
\hline Case 06 & & & & S.C.W (Soil Cement Wall) \\
\hline Case 07 & & & Sandy Soil & Sheet Pile \\
\hline Case 08 & & & & H-Pile + Earth Plate \\
\hline Case 09 & & & Soft Clay Soil & Sheet Pile \\
\hline Case 10 & & & & C.I.P (Cast-In-Placed pile) \\
\hline Case 11 & & \multirow{8}{*}{$\begin{array}{c}40 \\
\text { (Deep Excavation) }\end{array}$} & & S.C.W (Soil Cement Wall) \\
\hline Case 12 & & & Composite Soil & Sheet Pile \\
\hline Case 13 & & & & H-Pile + Earth Plate \\
\hline Case 14 & & & & C.I.P (Cast-In-Placed pile) \\
\hline Case 15 & & & & S.C.W (Soil Cement Wall) \\
\hline Case 16 & & & Sandy Soil & Sheet Pile \\
\hline Case 17 & & & & H-Pile+Earth Plate \\
\hline Case 18 & & & Soft Clay Soil & Sheet Pile \\
\hline
\end{tabular}


Table 3. Soil properties applied to the case analysis (Excavation area: $50 \mathrm{~m} \times 50 \mathrm{~m}$ ).

\begin{tabular}{|c|c|c|c|c|c|c|c|c|}
\hline $\begin{array}{l}\text { Excavation } \\
\text { Depth } \\
\text { (m) }\end{array}$ & $\begin{array}{c}\text { Soil } \\
\text { Condition }\end{array}$ & $\begin{array}{l}\text { Depth } \\
\text { (m) }\end{array}$ & $\begin{array}{c}\gamma_{\mathrm{t}} \\
\left(\mathrm{kN} / \mathrm{m}^{3}\right)\end{array}$ & $\begin{array}{c}\gamma_{\text {sat }} \\
\left(\mathrm{kN} / \mathrm{m}^{3}\right)\end{array}$ & $\begin{array}{c}c \\
\left(k N / m^{2}\right)\end{array}$ & $\begin{array}{c}\varphi \\
\text { (deg) }\end{array}$ & $\mathbf{N}$ & $\begin{array}{c}\text { Coefficient of } \\
\text { Horizontal } \\
\text { Subgrade } \\
\text { Reaction }\left(\mathrm{kN} / \mathrm{m}^{3}\right)\end{array}$ \\
\hline \multirow{12}{*}{15} & & 3 & \multirow{4}{*}{18} & \multirow{4}{*}{19} & 3 & 33 & 20 & 2200 \\
\hline & Composite & 8 & & & 8 & 35 & 25 & 7200 \\
\hline & \multirow[t]{2}{*}{ Soil } & 13 & & & 13 & 38 & 30 & 13,400 \\
\hline & & 25 & & & 35 & 42 & 40 & 18,000 \\
\hline & & 3 & \multirow{4}{*}{18} & \multirow{4}{*}{19} & \multirow{4}{*}{0} & 33 & 20 & 2000 \\
\hline & Sandy & 8 & & & & 35 & 25 & 6000 \\
\hline & Soil & 13 & & & & 38 & 30 & 12,000 \\
\hline & & 25 & & & & 42 & 40 & 15,000 \\
\hline & & 3 & \multirow{4}{*}{17} & \multirow{4}{*}{18} & 4 & 5 & 4 & 500 \\
\hline & Soft Clay & 8 & & & 7 & 10 & 8 & 1000 \\
\hline & \multirow[t]{3}{*}{ Soil } & 13 & & & 14 & 15 & 15 & 2000 \\
\hline & & 35 & & & 14 & 15 & 15 & 2000 \\
\hline \multirow{12}{*}{40} & & 5 & \multirow{5}{*}{18} & \multirow{4}{*}{19} & 4 & 33 & 20 & 2200 \\
\hline & Composite & 10 & & & 7 & 35 & 25 & 7200 \\
\hline & \multirow[t]{3}{*}{ Soil } & 15 & & & 14 & 38 & 30 & 13,400 \\
\hline & & 60 & & & 14 & 42 & 40 & 18,000 \\
\hline & & 5 & & \multirow{4}{*}{19} & & 33 & 20 & 2000 \\
\hline & & 10 & \multirow{3}{*}{18} & & \multirow{3}{*}{0} & 35 & 25 & 6000 \\
\hline & Sandy So1l & 15 & & & & 38 & 30 & 12,000 \\
\hline & & 60 & & & & 42 & 40 & 15,000 \\
\hline & & 5 & 17 & 18 & 4 & 4 & 20 & 500 \\
\hline & Soft Clay & 10 & 17 & 18 & 7 & 8 & 25 & 1000 \\
\hline & Soil & 15 & 17 & 18 & 14 & 15 & 30 & 2000 \\
\hline & & 60 & 17 & 18 & 15 & 17 & 40 & 2000 \\
\hline
\end{tabular}

The excavation area is medium-sized $(50 \times 50 \mathrm{~m})$, and the deepest excavation point (excavation depth: $40 \mathrm{~m}$ ) was determined to be $40 \mathrm{~m}$, a depth which makes the application of the construction method for a retaining wall clearly distinguished, in consideration of the maximum possible construction depth (less than $50 \mathrm{~m}$ allowed).

\subsection{Evaluation of Stability in Each Case}

The program used in the design case is Midas GeoX V.4.6.0. Earth pressure applied to the retaining wall causes stress and displacement of the structure. The deformation analysis of the retaining wall is generally performed by the elastoplastic analysis, because the stress and displacement of the retaining wall change depending on the excavation stage of ground. Midas GeoX V.4.6.0 allows the elastoplastic analysis considering the excavation stage.

All cases applied to the LCA analysis were assumed to have both internal and external stability at each excavation stage. The assessment of internal stability was conducted by a review of the cross-section of the structure (member), and the structural stability of H-Pile, C.I.P, Sheet Pile, S.C.W, Strut, Wale, etc., which form a wall, was evaluated by construction stage (excavation stage). External stability was evaluated by dividing it into the stability on the earth pressure acting on the retaining wall and the stability on the surrounding ground subsidence, etc. during the excavation stage and final excavation stages. Table 4 summarizes the application method of each item for the evaluation of stability performed for the earth-retaining wall in this study. 
Table 4. Method for review of stability by construction method and item.

\begin{tabular}{|c|c|c|}
\hline Classification & Construction Method or Item & Method for Review \\
\hline \multirow{3}{*}{$\begin{array}{l}\text { Member Sections } \\
\text { (Structural Analysis) }\end{array}$} & $\begin{array}{c}\text { H-Pile } \\
\text { Sheet Pile } \\
\text { C.I.P (Cast-In-Placed pile) } \\
\text { S.C.W (Soil Cement Wall) }\end{array}$ & $\begin{array}{c}\text { Review of Bending } \\
\text { Safety Review of Shear } \\
\text { Review of Axial Force (S.C.W) }\end{array}$ \\
\hline & Strut & $\begin{array}{c}\text { Review of Applied Load } \\
\text { Axial Force against Earth Pressure } \\
\text { Axial Force due to Temperature Change } \\
\text { Axial Force Applied to the Vertical Load and } \\
\text { Auxiliary Reinforcement }\end{array}$ \\
\hline & Wale & $\begin{array}{l}\text { Buckling Length } \\
\text { Section Review }\end{array}$ \\
\hline \multirow{4}{*}{ Excavation Face } & Embedded Depth & $\begin{array}{l}\text { Reviewing after Dividing it into the Final } \\
\text { Excavation and Pre-stage of Final Excavation }\end{array}$ \\
\hline & Surrounding Subsidence & $\begin{array}{c}\text { Final Excavation Stage } \\
\text { Review by Caspe (1966) Method }\end{array}$ \\
\hline & $\begin{array}{c}\text { Boiling } \\
\text { (Sandy Soil, Composite Soil) }\end{array}$ & $\begin{array}{c}\text { Final Excavation Stage } \\
\text { Terzaghi } \\
\text { Critical Hydraulic Gradient }\end{array}$ \\
\hline & Heaving (Soft Clay Soil) & $\begin{array}{c}\text { Final Excavation Stage } \\
\text { Method by Bearing Capacity Formula } \\
\text { Terzaghi-Peck (Review by Surcharge Load } \\
\text { Strength or Ultimate Bearing Capacity) } \\
\text { Bjerrum-O.Eide (Review by Rotational } \\
\text { Moment and Resisting Moment) }\end{array}$ \\
\hline
\end{tabular}

Figure 3 shows a schematic diagram of the numerical analysis carried out in this study. The underground water level is reflected in the analysis on the premise that it is lowered according to the stage of excavation and lowered to the excavation surface. The review of stability, such as the stability of the embedded unit, the stability of subsidence, and heaving in each case, considered only the impact on excavation depth because it was affected by the increase in stress depending on excavation depth and was independent of the excavation width.

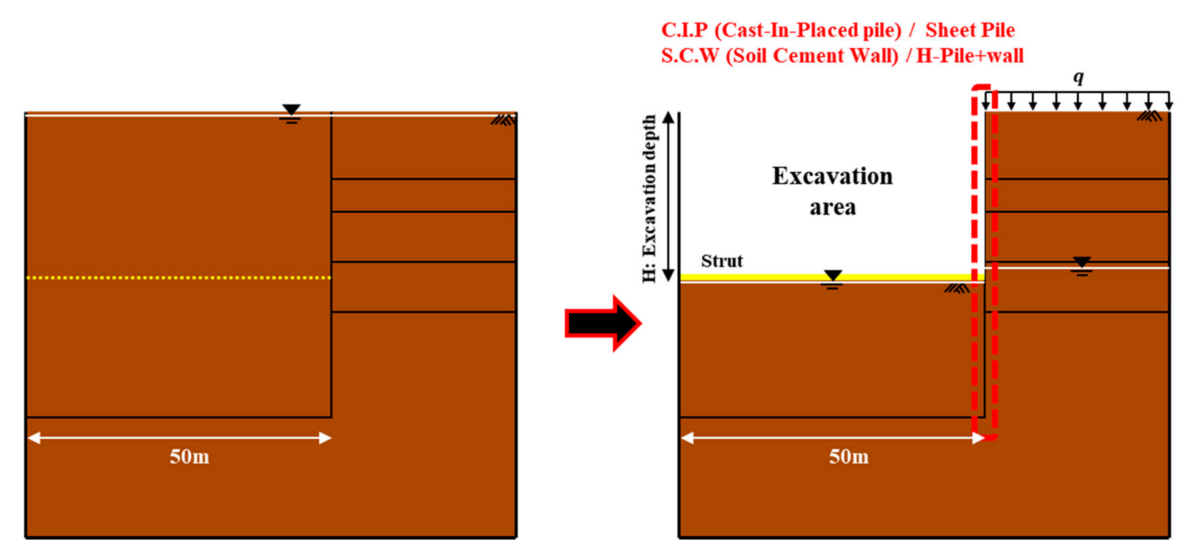

Figure 3. Schematic diagram of the numerical analysis.

Table 5 shows the results of the stability review for each case based on analysis conditions. First, in the stability evaluation of the embedded depth (required safety factor: 1.2) based on the Earth-retaining Wall Design Standard of the Ministry of Land, Infrastructure and Transport in Korea [43] for a shallow excavation depth, the safety factors 
are in the following orders from high to low: C.I.P, S.C.W, Sheet Pile, and H-Pile+Earth Plate construction method in the composite soil, and C.I.P, H-Pile, S.C.W, and Sheet Pile construction method in the sandy soil. For deep excavations in composite soil, the safety factors are in the following orders from high to low: S.C.W, C.I.P, Sheet Pile, and HPile+Earth Plate construction method. For deep excavations in sandy soil, they increase in the following order: C.I.P, S.C.W, Sheet Pile, and H-Pile+Earth Plate construction method. Furthermore, it was confirmed that the deeper the excavation depth, the greater the safety factor in soft clay ground.

Table 5. Stability review results by case.

\begin{tabular}{|c|c|c|c|c|c|c|c|c|}
\hline & & \multirow{3}{*}{ Stage } & \multicolumn{6}{|c|}{ Review Results } \\
\hline & & & \multirow{2}{*}{$\begin{array}{l}\text { Safety } \\
\text { Factor } \\
(=1.2)\end{array}$} & \multirow{2}{*}{$\begin{array}{c}\text { Maximum } \\
\text { Subsidence } \\
\text { around } \\
\text { Retaining Wall } \\
\text { (m) }\end{array}$} & \multicolumn{2}{|c|}{$\begin{array}{c}\text { Boiling } \\
\text { (Safety Factor } \\
\text { Criteria }=2.0 \text { ) }\end{array}$} & \multirow{2}{*}{$\begin{array}{c}\text { Heaving } \\
\text { (Safety Factor } \\
\text { Criteria }=1.2 \text { ) }\end{array}$} & \multirow{2}{*}{$\begin{array}{c}\text { Soil } \\
\text { Condition }\end{array}$} \\
\hline & & & & & $\begin{array}{l}\text { Terzaghi } \\
\text { Analysis }\end{array}$ & $\begin{array}{l}\text { Critical } \\
\text { Hydraulic } \\
\text { Gradient }\end{array}$ & & \\
\hline \multirow{8}{*}{$\begin{array}{l}\text { Excavation } \\
\text { Depth } \\
15 \mathrm{~m}\end{array}$} & Case 01 & $\begin{array}{l}\text { (1) } \\
\text { (2) }\end{array}$ & $\begin{array}{l}9.899 \\
9.010\end{array}$ & -0.005 & 5.400 & 6.300 & & \multirow{4}{*}{$\begin{array}{c}\text { Composite } \\
\text { Soil }\end{array}$} \\
\hline & Case 02 & $\begin{array}{l}\text { (1) } \\
\text { (2) }\end{array}$ & $\begin{array}{l}4.719 \\
6.424\end{array}$ & -0.008 & 5.400 & 6.300 & & \\
\hline & Case 03 & $\begin{array}{l}\text { (1) } \\
\text { (2) }\end{array}$ & $\begin{array}{l}4.719 \\
6.424\end{array}$ & -0.008 & 5.400 & 6.300 & & \\
\hline & Case 04 & $\begin{array}{l}\text { (1) } \\
\text { (2) }\end{array}$ & $\begin{array}{l}4.580 \\
3.820\end{array}$ & -0.010 & 2.700 & 3.600 & & \\
\hline & Case 05 & $\begin{array}{l}\text { (1) } \\
\text { (2) }\end{array}$ & $\begin{array}{l}3.456 \\
3.535\end{array}$ & -0.005 & 5.400 & 6.300 & & \multirow{4}{*}{ Sandy Soil } \\
\hline & Case 06 & (1) & $\begin{array}{l}1.598 \\
2.520\end{array}$ & -0.008 & 5.400 & 6.300 & & \\
\hline & Case 07 & $\begin{array}{l}\text { (1) } \\
\text { (2) }\end{array}$ & $\begin{array}{l}1.598 \\
2.520\end{array}$ & -0.010 & 5.400 & 6.300 & & \\
\hline & Case 08 & $\begin{array}{l}\text { (1) } \\
\text { (2) }\end{array}$ & $\begin{array}{l}3.097 \\
2.893\end{array}$ & -0.010 & 5.400 & 6.300 & & \\
\hline \multirow{10}{*}{$\begin{array}{l}\text { Excavation } \\
\text { Depth } \\
40 \mathrm{~m}\end{array}$} & Case 09 & $\begin{array}{l}\text { (1) } \\
\text { (2) }\end{array}$ & $\begin{array}{l}1.245 \\
2.889\end{array}$ & -0.073 & & & 2.652 & $\begin{array}{l}\text { Soft Clay } \\
\text { Soil }\end{array}$ \\
\hline & Case 10 & $\begin{array}{l}\text { (1) } \\
\text { (2) }\end{array}$ & $\begin{array}{l}1.972 \\
8.646\end{array}$ & -0.044 & 5.400 & 6.300 & & \multirow{4}{*}{$\begin{array}{c}\text { Composite } \\
\text { Soil }\end{array}$} \\
\hline & Case 11 & $\begin{array}{l}\text { (1) } \\
\text { (2) }\end{array}$ & $\begin{array}{c}2.499 \\
11.799\end{array}$ & -0.039 & 5.400 & 9.900 & & \\
\hline & Case 12 & $\begin{array}{l}\text { (1) } \\
\text { (2) }\end{array}$ & $\begin{array}{l}1.319 \\
5.368\end{array}$ & -0.047 & 9.000 & 6.300 & & \\
\hline & Case 13 & $\begin{array}{l}\text { (1) } \\
\text { (2) }\end{array}$ & $\begin{array}{l}2.755 \\
4.309\end{array}$ & -0.044 & 5.400 & 6.300 & & \\
\hline & Case 14 & (1) & $\begin{array}{l}1.284 \\
6.090\end{array}$ & -0.067 & 5.400 & 11.700 & & \multirow{4}{*}{ Sandy Soil } \\
\hline & Case 15 & $\begin{array}{l}\text { (1) } \\
\text { (2) }\end{array}$ & $\begin{array}{l}1.346 \\
5.085\end{array}$ & -0.048 & 10.800 & 15.300 & & \\
\hline & Case 16 & $\begin{array}{l}\text { (1) } \\
\text { (2) }\end{array}$ & $\begin{array}{l}1.333 \\
4.510\end{array}$ & -0.120 & 14.400 & 6.300 & & \\
\hline & Case 17 & $\begin{array}{l}\text { (1) } \\
\text { (2) }\end{array}$ & $\begin{array}{l}1.753 \\
2.605\end{array}$ & -0.069 & 5.400 & 6.300 & & \\
\hline & Case 18 & $\begin{array}{l}\text { (1) } \\
\text { (2) }\end{array}$ & $\begin{array}{l}1.696 \\
8.371\end{array}$ & -0.256 & & & 3.791 & $\begin{array}{l}\text { Soft Clay } \\
\text { Soil }\end{array}$ \\
\hline
\end{tabular}

Caspe [44] estimation of subsidence on the soil was based on a method redefined by Bowles [45], which is relatively consistent with actual data. However, this method has the premise that the displacement (subsidence) due to an increase in effective stress 
caused by a drop in groundwater level should be calculated separately. As input data for analysis, lateral displacement of the wall by depth, excavation depth, excavation width, and shear resistance angle are required, and for lateral displacement of the wall, computerized analysis data using the beam on elasto-plastic foundation analysis were used.

The deeper the excavation depth, the larger the maximum subsidence, and subsidence occurred more in sandy soil than in composite ground. In addition, in composite soil, when the excavation depth is shallow, the H-Pile+Earth Plate construction method produces the largest amount of subsidence, but the deeper the excavation depth, the greater the subsidence in the Sheet Pile construction method. When the excavation depth is shallow in sandy soil, the Sheet Pile and the H-Pile+Earth Plate construction methods have the largest subsidence, and the C.I.P construction method has the smallest subsidence. When the excavation depth is deep, the Sheet Pile construction method has the largest subsidence, and the S.C.W. construction method has the smallest one. Meanwhile, in soft clay ground, the deeper the excavation depth, the more rapidly the subsidence increases. This result is based on the design of the retaining wall structure with secured stability, so only a very small amount of subsidence occurs; only the tendency of the occurrence of subsidence was analyzed.

Boiling on the bottom of an excavation is generally assessed to increase the safety factor as excavation depth increases, and at this time, the safety factor applied to the boiling judgment was 2.0 [43]. When the excavation depth is shallow, in composite soil, the H-Pile+Earth Plate construction method has a smaller safety factor than do the other construction methods. In sandy soil, as the excavation depth increases, the safety factor increases rapidly, and the safety factor is high in the order of Sheet Pile, S.C.W, C.I.P, and H-Pile+Earth Plate construction method. On the other hand, if pile stiffness and penetration depth are met, a review of heaving is considered in the soft clay layer, so in Sheet Pile application, the deeper the excavation depth, the greater the calculated safety factor necessary to meet the safety factor requirements. The required safety factor was applied to 1.2 [43].

\section{Analysis of LCA on Earth-Retaining Wall}

\subsection{Method and Scope of the Evaluation of Environmental Impact Assessment}

LCA analysis was performed on the applicable construction method of an earthretaining wall by each installation condition, and then the environmental impact characteristics were analyzed. In Korea, the environmental impact assessment of earth-retaining wall is considered as a temporary structure, which reflects only the production and consumption of input resources in the construction stage. Therefore, construction details of material and equipment usage, standards of construction estimates, and energy statistics data of Korea were used to perform inventory analysis on all items applied to the construction of the earth-retaining wall method in this study. In addition, the LCI DB of the Ministry of Environment (MOE) and Ministry of Trade, Industry and Energy (MPTIE) of Korea was used for inventory analysis of the surveyed resources that were required. LCA software (Tool for TypeIII Labeling and LCA, hereinafter referred to as TOTAL) suggested by the Ministry of Environment in Korea was used. The environmental impact assessment was performed on the temporary earth protection facility based on the results after inventory analysis for each case object was performed. Abiotic resource depletion (ARD), global warming $(\mathrm{GW})$, ozone depletion (OD), photochemical oxidant creation (POC), and acidification (AC), eutrophication (EU), ecotoxicity (ET), and human toxicity (HT) were applied as impact categories in order to establish the evaluation comparison criterion. In the environmental load assessment, the construction cost considering the construction method and ground conditions of the earth-retaining wall was applied based on standard of construction estimates in Korea [46]. 


\subsection{LCA Results of the Earth-Retaining Wall According to Excavation Depth}

\subsubsection{Evaluation Results of Environment Load}

Tables 6 and 7 and Figure 4 show the results of identifying and evaluating major environmental impacts through list analysis and impact assessment results for cases where the excavation area is medium scale $(50 \times 50 \mathrm{~m})$ in shallow excavation $(15 \mathrm{~m})$ and deep excavation $(40 \mathrm{~m})$ depending on the ground conditions.

Table 6. Results of environmental load (shallow excavation: $\mathrm{H}=15 \mathrm{~m}$ ).

\begin{tabular}{|c|c|c|c|c|c|}
\hline \multirow{2}{*}{$\begin{array}{l}\text { Environmental } \\
\text { Impact Factor }\end{array}$} & \multirow{2}{*}{ Soil Condition } & \multicolumn{4}{|c|}{ Construction Method } \\
\hline & & C.I.P & S.C.W & Sheet Pile & H-Pile+Earth Plate \\
\hline Abiotic Resource & Composite Soil & $2.50 \times 10^{-5}$ & $2.58 \times 10^{-5}$ & $1.59 \times 10^{-5}$ & $1.59 \times 10^{-5}$ \\
\hline $\begin{array}{c}\text { Depletion } \\
\text { (ARD) }\end{array}$ & $\begin{array}{l}\text { Sandy Soil } \\
\text { Soft Clay Soil }\end{array}$ & $2.56 \times 10^{-5}$ & $2.67 \times 10^{-5}$ & $\begin{array}{l}1.79 \times 10^{-5} \\
4.01 \times 10^{-5}\end{array}$ & $1.74 \times 10^{-5}$ \\
\hline $\begin{array}{l}\text { Global Warming } \\
\text { (GW) }\end{array}$ & $\begin{array}{l}\text { Composite Soil } \\
\text { Sandy Soil } \\
\text { Soft Clay Soil }\end{array}$ & $\begin{array}{l}5.37 \times 10^{-5} \\
5.64 \times 10^{-5}\end{array}$ & $\begin{array}{l}5.49 \times 10^{-5} \\
5.80 \times 10^{-5}\end{array}$ & $\begin{array}{l}2.70 \times 10^{-5} \\
3.08 \times 10^{-5} \\
6.78 \times 10^{-5}\end{array}$ & $\begin{array}{l}5.94 \times 10^{-5} \\
6.22 \times 10^{-5}\end{array}$ \\
\hline $\begin{array}{l}\text { Ozone Depletion } \\
\text { (OD) }\end{array}$ & $\begin{array}{l}\text { Composite Soil } \\
\text { Sandy Soil } \\
\text { Soft Clay Soil }\end{array}$ & $\begin{array}{l}1.40 \times 10^{-7} \\
1.36 \times 10^{-7}\end{array}$ & $\begin{array}{l}1.41 \times 10^{-7} \\
1.40 \times 10^{-7}\end{array}$ & $\begin{array}{l}1.37 \times 10^{-7} \\
1.52 \times 10^{-7} \\
3.48 \times 10^{-7}\end{array}$ & $\begin{array}{l}2.25 \times 10^{-7} \\
2.38 \times 10^{-7}\end{array}$ \\
\hline Photochemical & Composite Soil & $2.24 \times 10^{-7}$ & $2.35 \times 10^{-7}$ & $1.32 \times 10^{-7}$ & $3.87 \times 10^{-7}$ \\
\hline $\begin{array}{c}\text { Oxidant Creation } \\
\text { (POC) }\end{array}$ & $\begin{array}{l}\text { Sandy Soil } \\
\text { Soft Clay Soil }\end{array}$ & $2.35 \times 10^{-7}$ & $2.48 \times 10^{-7}$ & $\begin{array}{l}1.50 \times 10^{-7} \\
3.32 \times 10^{-7}\end{array}$ & $4.00 \times 10^{-7}$ \\
\hline $\begin{array}{l}\text { Acidification } \\
\text { (AC) }\end{array}$ & $\begin{array}{l}\text { Composite Soil } \\
\text { Sandy Soil } \\
\text { Soft Clay Soil }\end{array}$ & $\begin{array}{l}2.00 \times 10^{-6} \\
2.13 \times 10^{-6}\end{array}$ & $\begin{array}{l}1.98 \times 10^{-6} \\
2.13 \times 10^{-6}\end{array}$ & $\begin{array}{l}1.37 \times 10^{-6} \\
1.57 \times 10^{-6} \\
3.45 \times 10^{-6}\end{array}$ & $\begin{array}{l}1.33 \times 10^{-6} \\
1.47 \times 10^{-6}\end{array}$ \\
\hline $\begin{array}{l}\text { Eutrophication } \\
\text { (EU) }\end{array}$ & $\begin{array}{l}\text { Composite Soil } \\
\text { Sandy Soil } \\
\text { Soft Clay Soil }\end{array}$ & $\begin{array}{l}3.47 \times 10^{-9} \\
3.60 \times 10^{-9}\end{array}$ & $\begin{array}{l}3.41 \times 10^{-9} \\
3.58 \times 10^{-9}\end{array}$ & $\begin{array}{l}2.21 \times 10^{-9} \\
2.50 \times 10^{-9} \\
5.58 \times 10^{-9}\end{array}$ & $\begin{array}{l}8.20 \times 10^{-9} \\
8.42 \times 10^{-9}\end{array}$ \\
\hline $\begin{array}{l}\text { Ecotoxicity } \\
\text { (ET) }\end{array}$ & $\begin{array}{l}\text { Composite Soil } \\
\text { Sandy Soil } \\
\text { Soft Clay Soil }\end{array}$ & $\begin{array}{l}6.91 \times 10^{-6} \\
7.04 \times 10^{-6}\end{array}$ & $\begin{array}{l}6.96 \times 10^{-6} \\
7.19 \times 10^{-6}\end{array}$ & $\begin{array}{l}5.16 \times 10^{-6} \\
5.78 \times 10^{-6} \\
1.30 \times 10^{-5}\end{array}$ & $\begin{array}{l}5.45 \times 10^{-4} \\
5.46 \times 10^{-4}\end{array}$ \\
\hline $\begin{array}{c}\text { Human Toxicity } \\
(\mathrm{HT})\end{array}$ & $\begin{array}{l}\text { Composite Soil } \\
\text { Sandy Soil } \\
\text { Soft Clay Soil }\end{array}$ & $\begin{array}{l}4.53 \times 10^{-6} \\
4.49 \times 10^{-6}\end{array}$ & $\begin{array}{l}4.63 \times 10^{-6} \\
4.64 \times 10^{-6}\end{array}$ & $\begin{array}{l}2.49 \times 10^{-6} \\
2.76 \times 10^{-6} \\
2.76 \times 10^{-6}\end{array}$ & $\begin{array}{l}3.79 \times 10^{-6} \\
4.03 \times 10^{-6}\end{array}$ \\
\hline Total & $\begin{array}{l}\text { Composite Soil } \\
\text { Sandy Soil } \\
\text { Soft Clay Soil }\end{array}$ & $\begin{array}{l}9.24 \times 10^{-5} \\
9.60 \times 10^{-5}\end{array}$ & $\begin{array}{l}9.47 \times 10^{-5} \\
9.91 \times 10^{-5}\end{array}$ & $\begin{array}{l}5.21 \times 10^{-5} \\
5.90 \times 10^{-5} \\
1.31 \times 10^{-4}\end{array}$ & $\begin{array}{l}6.26 \times 10^{-4} \\
6.32 \times 10^{-4}\end{array}$ \\
\hline
\end{tabular}

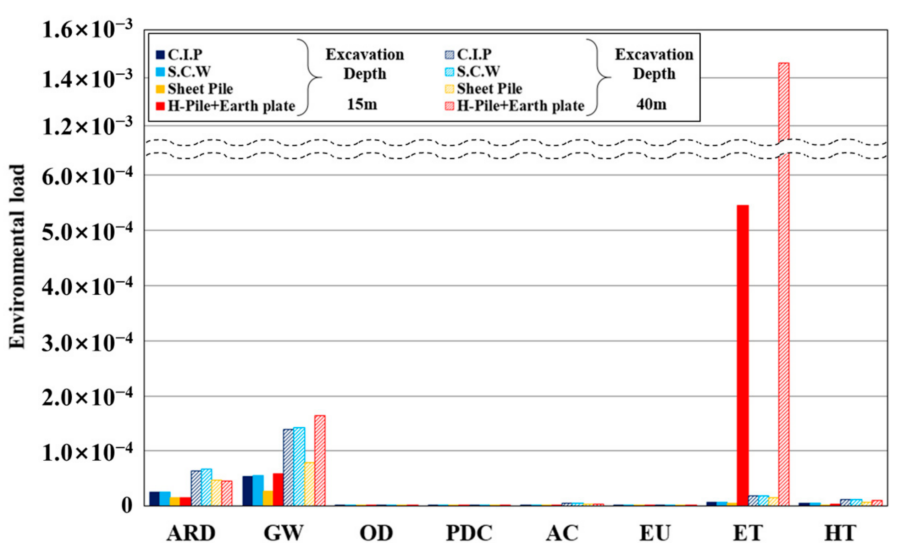

(a)

Figure 4. Cont. 


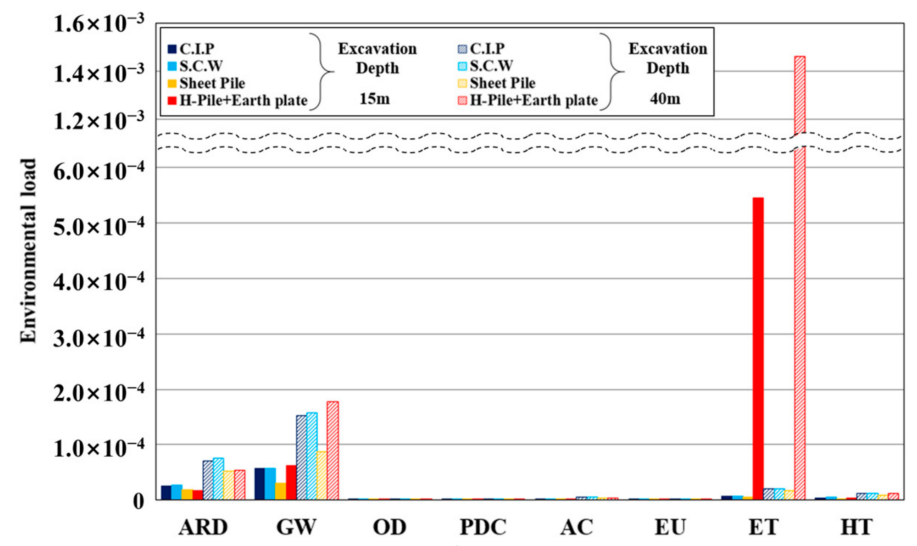

(b)

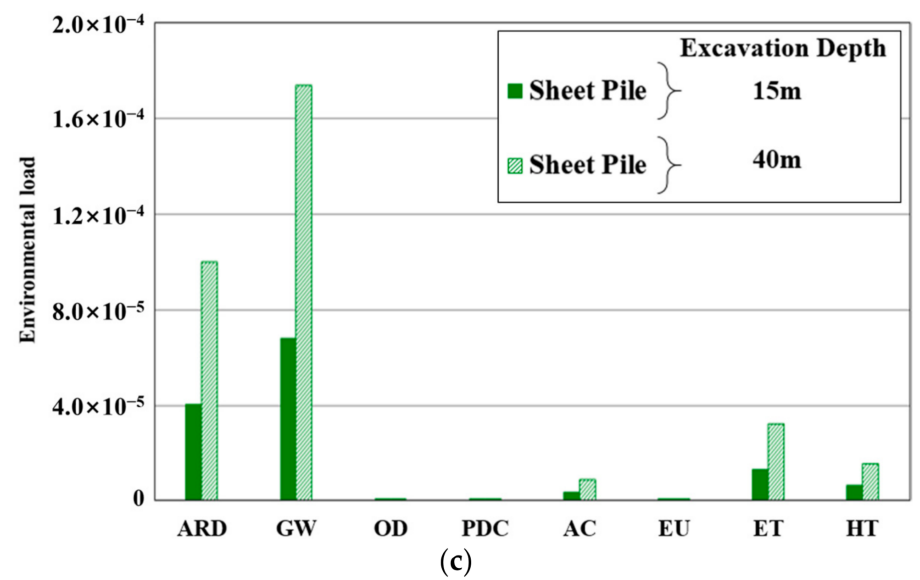

Figure 4. Relationship between environmental impact factor and environmental load by soil condition (excavation depth 15 m, 40 m): (a) composite soil; (b) sandy soil; (c) soft clay soil.

Table 7. Results of environmental load (deep excavation: $\mathrm{H}=40 \mathrm{~m}$ ).

\begin{tabular}{|c|c|c|c|c|c|}
\hline \multirow{2}{*}{$\begin{array}{l}\text { Environmental } \\
\text { Impact Factor }\end{array}$} & \multirow{2}{*}{ Soil Condition } & \multicolumn{4}{|c|}{ Construction Method } \\
\hline & & C.I.P & S.C.W & Sheet Pile & H-Pile+Earth Plate \\
\hline Abiotic Resource & Composite Soil & $6.45 \times 10^{-5}$ & $6.76 \times 10^{-5}$ & $4.72 \times 10^{-5}$ & $4.58 \times 10^{-5}$ \\
\hline $\begin{array}{l}\text { Depletion } \\
\text { (ARD) }\end{array}$ & $\begin{array}{l}\text { Sandy Soil } \\
\text { Soft Clay Soil }\end{array}$ & $7.07 \times 10^{-5}$ & $7.49 \times 10^{-5}$ & $\begin{array}{l}5.19 \times 10^{-5} \\
1.00 \times 10^{-4}\end{array}$ & $5.30 \times 10^{-5}$ \\
\hline $\begin{array}{l}\text { Global Warming } \\
\qquad(\mathrm{GW})\end{array}$ & $\begin{array}{l}\text { Composite Soil } \\
\text { Sandy Soil } \\
\text { Soft Clay Soil }\end{array}$ & $\begin{array}{l}1.39 \times 10^{-4} \\
1.52 \times 10^{-4}\end{array}$ & $\begin{array}{l}1.43 \times 10^{-4} \\
1.58 \times 10^{-4}\end{array}$ & $\begin{array}{l}7.94 \times 10^{-5} \\
8.75 \times 10^{-5} \\
1.74 \times 10^{-4}\end{array}$ & $\begin{array}{l}1.65 \times 10^{-4} \\
1.77 \times 10^{-4}\end{array}$ \\
\hline $\begin{array}{l}\text { Ozone Depletion } \\
\text { (OD) }\end{array}$ & $\begin{array}{l}\text { Composite Soil } \\
\text { Sandy Soil } \\
\text { Soft Clay Soil }\end{array}$ & $\begin{array}{l}3.64 \times 10^{-7} \\
4.02 \times 10^{-7}\end{array}$ & $\begin{array}{l}3.77 \times 10^{-7} \\
4.24 \times 10^{-7}\end{array}$ & $\begin{array}{l}4.13 \times 10^{-7} \\
4.52 \times 10^{-7} \\
8.39 \times 10^{-7}\end{array}$ & $\begin{array}{l}6.27 \times 10^{-7} \\
6.88 \times 10^{-7}\end{array}$ \\
\hline Photochemical & Composite Soil & $5.84 \times 10^{-7}$ & $6.19 \times 10^{-7}$ & $3.89 \times 10^{-7}$ & $1.06 \times 10^{-6}$ \\
\hline $\begin{array}{c}\text { Oxidant Creation } \\
\text { (POC) }\end{array}$ & $\begin{array}{l}\text { Sandy Soil } \\
\text { Soft Clay Soil }\end{array}$ & $6.44 \times 10^{-7}$ & $6.87 \times 10^{-7}$ & $\begin{array}{l}4.28 \times 10^{-7} \\
8.46 \times 10^{-7}\end{array}$ & $1.12 \times 10^{-6}$ \\
\hline $\begin{array}{l}\text { Acidification } \\
\text { (AC) }\end{array}$ & $\begin{array}{l}\text { Composite Soil } \\
\text { Sandy Soil } \\
\text { Soft Clay Soil }\end{array}$ & $\begin{array}{l}5.32 \times 10^{-6} \\
5.96 \times 10^{-6}\end{array}$ & $\begin{array}{l}5.36 \times 10^{-6} \\
6.08 \times 10^{-6}\end{array}$ & $\begin{array}{l}4.05 \times 10^{-6} \\
4.46 \times 10^{-6} \\
8.86 \times 10^{-6}\end{array}$ & $\begin{array}{l}3.88 \times 10^{-6} \\
4.50 \times 10^{-6}\end{array}$ \\
\hline $\begin{array}{l}\text { Eutrophication } \\
\text { (EU) }\end{array}$ & $\begin{array}{l}\text { Composite Soil } \\
\text { Sandy Soil } \\
\text { Soft Clay Soil }\end{array}$ & $\begin{array}{l}9.04 \times 10^{-9} \\
9.97 \times 10^{-9}\end{array}$ & $\begin{array}{l}9.05 \times 10^{-9} \\
1.01 \times 10^{-8}\end{array}$ & $\begin{array}{l}6.56 \times 10^{-9} \\
7.22 \times 10^{-9} \\
1.41 \times 10^{-8}\end{array}$ & $\begin{array}{l}2.24 \times 10^{-8} \\
2.34 \times 10^{-8}\end{array}$ \\
\hline
\end{tabular}


Table 7. Cont.

\begin{tabular}{|c|c|c|c|c|c|}
\hline \multirow{2}{*}{$\begin{array}{l}\text { Environmental } \\
\text { Impact Factor }\end{array}$} & \multirow{2}{*}{ Soil Condition } & \multicolumn{4}{|c|}{ Construction Method } \\
\hline & & C.I.P & S.C.W & Sheet Pile & H-Pile+Earth Plate \\
\hline \multirow{3}{*}{$\begin{array}{c}\text { Ecotoxicity } \\
\text { (ET) }\end{array}$} & Composite Soil & $1.80 \times 10^{-5}$ & $1.85 \times 10^{-5}$ & $1.54 \times 10^{-5}$ & $1.46 \times 10^{-3}$ \\
\hline & Sandy Soil & $1.99 \times 10^{-5}$ & $2.07 \times 10^{-5}$ & $1.69 \times 10^{-5}$ & $1.46 \times 10^{-3}$ \\
\hline & Soft Clay Soil & & & $3.23 \times 10^{-5}$ & \\
\hline \multirow{3}{*}{$\begin{array}{l}\text { Human Toxicity } \\
\text { (HT) }\end{array}$} & Composite Soil & $1.14 \times 10^{-5}$ & $1.18 \times 10^{-5}$ & $7.47 \times 10^{-6}$ & $1.06 \times 10^{-5}$ \\
\hline & Sandy Soil & $1.21 \times 10^{-5}$ & $1.27 \times 10^{-5}$ & $8.19 \times 10^{-6}$ & $1.17 \times 10^{-5}$ \\
\hline & Soft Clay Soil & & & $1.53 \times 10^{-5}$ & \\
\hline \multirow{3}{*}{ Total } & Composite Soil & $2.39 \times 10^{-4}$ & $2.48 \times 10^{-4}$ & $1.54 \times 10^{-4}$ & $1.68 \times 10^{-3}$ \\
\hline & Sandy Soil & $2.62 \times 10^{-4}$ & $2.74 \times 10^{-4}$ & $1.70 \times 10^{-4}$ & $1.71 \times 10^{-3}$ \\
\hline & Soft Clay Soil & & & $3.33 \times 10^{-4}$ & \\
\hline
\end{tabular}

First, in the composite soil condition of shallow excavation (as shown in Table 6), the environmental load of the H-Pile+Earth Plate construction method was the highest, at $6.26 \times 10^{-4}$, which shows that the impact of the environmental load was great due to the use of wood. Next, the environmental loads were high in the S.C.W, C.I.P, and Sheet Pile construction methods, in that order. In the environmental impact factor, the H-Pile+Earth Plate construction method showed the highest ecological toxicity, and the other three construction methods (C.I.P, S.C.W, and Sheet Pile) showed the highest environmental load in the order of global warming and resource depletion. In the composite soil condition of deep excavation, (as shown in Table 7), the environmental load of the H-Pile+Earth Plate construction method for the earth-retaining wall was $1.68 \times 10^{-3}$ (the highest), and the environmental load of the other construction methods was high in the following order: S.C.W, C.I.P and Sheet Pile. Considering the environmental impact factor, the H-Pile+Earth Plate construction method had the largest environmental load for ecotoxicity, and the environmental load of the other three construction methods was high in the order of global warming and resource depletion.

Second, in the sandy soil condition of shallow excavation (as shown in Table 6), out of the four construction methods for the earth-retaining wall, the environmental load of H-Pile+Earth Plate was the highest $\left(6.32 \times 10^{-4}\right)$, and the environmental load was high in the order of S.C.W., C.I.P, and Sheet Pile. When compared by environmental impact factor, the H-Pile+Earth Plate construction method had the highest environmental load for ecotoxicity, and the environmental loads of the other three construction methods were high in the order of global warming, resources depletion, and ecotoxicity. The impact of global warming and resource depletion was greater than that of the other environmental impact categories. Moreover, in the sandy soil condition of deep excavation (as shown in Table 7), the environmental load of the H-Pile+Earth Plate construction method out of four construction methods for the earth-retaining wall was $1.71 \times 10^{-3}$, followed by the remaining three in the order of S.C.W, C.I.P, and Sheet Pile construction method. According to the environmental impact categories, the environmental load of ecotoxicity in the $\mathrm{H}$ Pile+Earth Plate construction method was the highest, and the environmental load of the other three construction methods was high for global warming, resource depletion, and ecotoxicity, in that order.

Third, in soft clay ground in shallow excavation (as shown in Table 6), the environmental load of the Sheet Pile construction method was $1.31 \times 10^{-4}$, and the environmental load was high in the order of global warming and resource depletion among all categories of environmental impact. Additionally, the environmental load of the Sheet Pile construction method in soft clay ground was much higher than that of the other soil conditions, and the worse the condition of the soil, the greater the associated environmental load because of the need for more input resources (e.g., reinforcing materials, etc.). In soft clay ground in deep excavation (as shown in Table 7), the environmental load for the Sheet Pile construction method was $3.33 \times 10^{-4}$, and according to the environmental impact factor, the environmental load amount was associated with global warming and resource depletion 
in that order. Compared to the Sheet Pile construction method in other soil conditions, the Sheet Pile construction method in soft clay soil had a higher environmental load.

\subsubsection{Evaluation Results of Environment Cost}

Tables 8 and 9 and Figure 5 show the results of identifying and evaluating major environmental impacts through list analysis and impact assessment results following the purpose and scope for cases where the excavation area is of medium scale $(50 \times 50 \mathrm{~m})$ in shallow excavation $(15 \mathrm{~m})$ and deep excavation $(40 \mathrm{~m})$ depending on the ground conditions. On this basis, in order to evaluate the environmental and economic impacts of the earth-retaining wall, evaluation of environmental economic feasibility was conducted by applying the environmental cost per unit of pollutants based on the environmental impact factor to the characteristics results of the environmental load amount for the eight categories previously calculated.

Table 8. Results of environmental cost * (shallow excavation: $\mathrm{H}=15 \mathrm{~m}$ ).

\begin{tabular}{|c|c|c|c|c|c|}
\hline \multirow{2}{*}{$\begin{array}{l}\text { Environmental } \\
\text { Impact Factor }\end{array}$} & \multirow{2}{*}{ Soil Condition } & \multicolumn{4}{|c|}{ Construction Method } \\
\hline & & C.I.P & S.C.W & Sheet Pile & H-Pile+Earth Plate \\
\hline Abiotic Resource & Composite Soil & 0.9 & 0.9 & 0.6 & 0.6 \\
\hline \multirow{2}{*}{$\begin{array}{c}\text { Depletion } \\
\text { (ARD) }\end{array}$} & Sandy Soil & 29.7 & 30.6 & 16.3 & 32.9 \\
\hline & Soft Clay Soil & & & 1.4 & \\
\hline \multirow{3}{*}{$\begin{array}{c}\text { Global Warming } \\
\text { (GW) }\end{array}$} & Composite Soil & 28.3 & 29.2 & 14.3 & 31.4 \\
\hline & Sandy Soil & 28.3 & 29.2 & 14.3 & 31.4 \\
\hline & Soft Clay Soil & & & 36.0 & \\
\hline \multirow{3}{*}{$\begin{array}{l}\text { Ozone Depletion } \\
\text { (OD) }\end{array}$} & Composite Soil & 0.0 & 0.0 & 0.0 & 0.0 \\
\hline & Sandy Soil & 0.0 & 0.0 & 0.0 & 0.0 \\
\hline & Soft Clay Soil & & & 0.0 & \\
\hline Photochemical & Composite Soil & 0.0 & 0.0 & 0.0 & 0.0 \\
\hline \multirow{2}{*}{$\begin{array}{l}\text { Oxidant Creation } \\
\qquad(\mathrm{POC})\end{array}$} & Sandy Soil & 0.0 & 0.0 & 0.0 & 0.0 \\
\hline & Soft Clay Soil & & & 0.0 & \\
\hline \multirow{3}{*}{$\begin{array}{c}\text { Acidification } \\
\text { (AC) }\end{array}$} & Composite Soil & 0.2 & 0.2 & 0.1 & 0.1 \\
\hline & Sandy Soil & 0.2 & 0.2 & 0.1 & 0.1 \\
\hline & Soft Clay Soil & & & 0.3 & \\
\hline \multirow{3}{*}{$\begin{array}{l}\text { Eutrophication } \\
\text { (EU) }\end{array}$} & Composite Soil & 0.0 & 0.0 & 0.0 & 0.0 \\
\hline & Sandy Soil & 0.0 & 0.0 & 0.0 & 0.0 \\
\hline & Soft Clay Soil & & & 0.0 & \\
\hline \multirow{3}{*}{$\begin{array}{l}\text { Ecotoxicity } \\
\quad(\mathrm{ET})\end{array}$} & Composite Soil & 1.2 & 1.2 & 0.9 & 90.9 \\
\hline & Sandy Soil & 1.2 & 1.2 & 1.0 & 90.9 \\
\hline & Soft Clay Soil & & & 2.2 & \\
\hline \multirow{3}{*}{$\begin{array}{l}\text { Human Toxicity } \\
\text { (HT) }\end{array}$} & Composite Soil & 6.4 & 6.5 & 3.5 & 5.3 \\
\hline & Sandy Soil & 6.3 & 6.5 & 3.9 & 5.7 \\
\hline & Soft Clay Soil & & & 8.9 & \\
\hline \multirow{3}{*}{ Total } & Composite Soil & 36.9 & 37.9 & 19.3 & 128.3 \\
\hline & Sandy Soil & 38.3 & 39.5 & 21.9 & 130.2 \\
\hline & Soft Clay Soil & & & 48.7 & \\
\hline
\end{tabular}

${ }^{*}$ Environmental cost(E-Cost) unit: KRW 1 million.

Table 9. Results of environmental cost * (deep excavation: $\mathrm{H}=40 \mathrm{~m}$ ).

\begin{tabular}{cccccc}
\hline \multirow{2}{*}{$\begin{array}{c}\text { Environmental } \\
\text { Impact Factor }\end{array}$} & Soil Condition & \multicolumn{3}{c}{ Construction Method } \\
\cline { 3 - 6 } & & C.I.P & S.C.W & Sheet Pile & H-Pile+Earth Plate \\
\hline Abiotic Resource & Composite Soil & 2.3 & 2.4 & 1.7 & 1.7 \\
Depletion & Sandy Soil & 2.6 & 2.7 & 1.9 & 1.9 \\
(ARD) & Soft Clay Soil & & & 3.6 & \\
Global Warming & Composite Soil & 73.4 & 75.9 & 41.9 & 87.2 \\
(GW) & Sandy Soil & 80.4 & 83.8 & 46.4 & 93.7 \\
\hline
\end{tabular}


Table 9. Cont.

\begin{tabular}{|c|c|c|c|c|c|}
\hline \multirow{2}{*}{$\begin{array}{l}\text { Environmental } \\
\text { Impact Factor }\end{array}$} & \multirow{2}{*}{ Soil Condition } & \multicolumn{4}{|c|}{ Construction Method } \\
\hline & & C.I.P & S.C.W & Sheet Pile & H-Pile+Earth Plate \\
\hline \multirow{3}{*}{$\begin{array}{l}\text { Ozone Depletion } \\
\text { (OD) }\end{array}$} & Composite Soil & 0.0 & 0.0 & 0.0 & 0.0 \\
\hline & Sandy Soil & 0.0 & 0.0 & 0.0 & 0.0 \\
\hline & Soft Clay Soil & & & 0.0 & \\
\hline Photochemical & Composite Soil & 0.0 & 0.0 & 0.0 & 0.0 \\
\hline \multirow{2}{*}{$\begin{array}{c}\text { Oxidant Creation } \\
\text { (POC) }\end{array}$} & Sandy Soil & 0.0 & 0.0 & 0.0 & 0.0 \\
\hline & Soft Clay Soil & & & 0.0 & \\
\hline \multirow{3}{*}{$\begin{array}{l}\text { Acidification } \\
\text { (AC) }\end{array}$} & Composite Soil & 0.4 & 0.4 & 0.3 & 0.3 \\
\hline & Sandy Soil & 0.5 & 0.5 & 0.3 & 0.3 \\
\hline & Soft Clay Soil & & & 0.7 & \\
\hline \multirow{3}{*}{$\begin{array}{l}\text { Eutrophication } \\
\text { (EU) }\end{array}$} & Composite Soil & 0.0 & 0.0 & 0.0 & 0.0 \\
\hline & Sandy Soil & 0.0 & 0.0 & 0.0 & 0.0 \\
\hline & Soft Clay Soil & & & 0.0 & \\
\hline \multirow{3}{*}{$\begin{array}{l}\text { Ecotoxicity } \\
\text { (ET) }\end{array}$} & Composite Soil & 3.0 & 3.1 & 2.6 & 242.5 \\
\hline & Sandy Soil & 3.3 & 3.4 & 2.8 & 243.4 \\
\hline & Soft Clay Soil & & & 0.0 & \\
\hline \multirow{3}{*}{$\begin{array}{c}\text { Human Toxicity } \\
(\mathrm{HT})\end{array}$} & Composite Soil & 16.0 & 16.6 & 10.5 & 14.9 \\
\hline & Sandy Soil & 17.1 & 17.9 & 11.6 & 16.5 \\
\hline & Soft Clay Soil & & & 21.6 & \\
\hline \multirow{3}{*}{ Total } & Composite Soil & 95.1 & 98.4 & 57.0 & 346.6 \\
\hline & Sandy Soil & 103.9 & 108.4 & 63.0 & 355.9 \\
\hline & Soft Clay Soil & & & 123.6 & \\
\hline
\end{tabular}

${ }^{*}$ Environmental cost(E-Cost) unit: KRW 1 million.
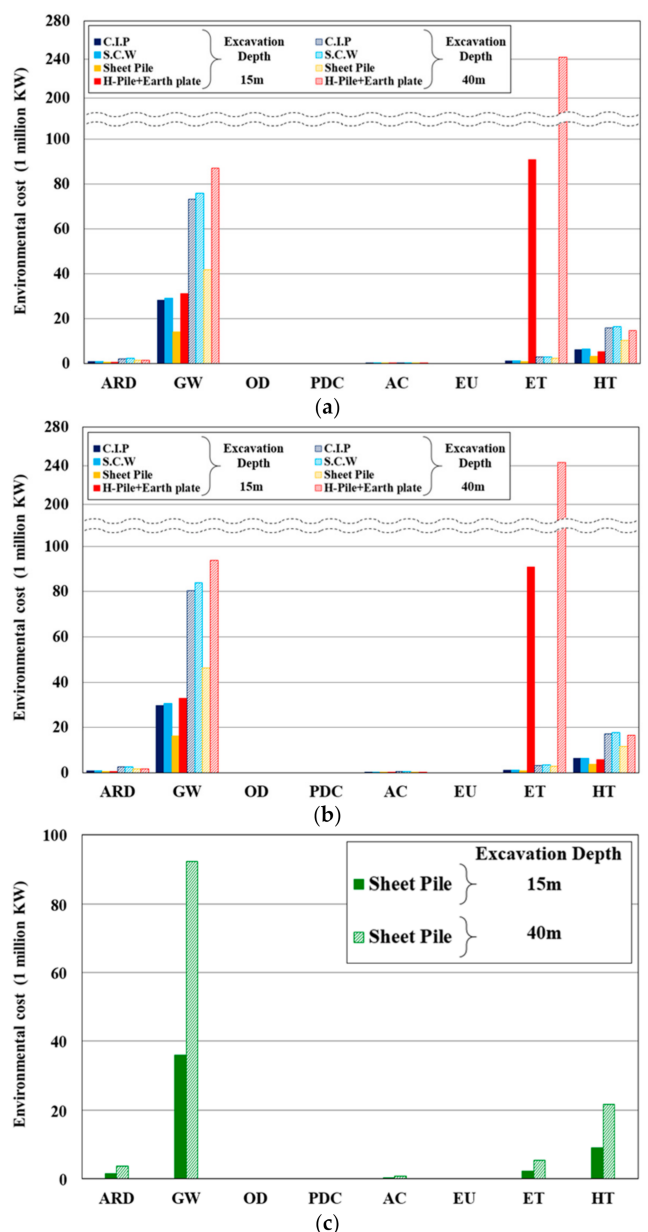

Figure 5. Relationship between environmental impact factor and environmental cost by soil condition (excavation depth 15 m, 40 m): (a) composite soil; (b) sandy soil; (c) soft clay soil. 
First, in the composite soil condition of shallow excavation (as shown in Table 8), the H-Pile+Earth Plate construction method showed the highest environmental cost for ecotoxicity at KRW 90.9 million, and the other three construction methods had the largest environmental costs due to global warming. Thus, when it comes to the expected total environmental costs at the construction stages for each installation condition of the construction methods for the earth-retaining wall considering all environmental costs corresponding to the eight environmental impact categories, the total environmental cost of the H-Pile+Earth Plate construction method is the highest (KRW 128.3 million), and the total environmental costs are high in the order of S.C.W, C.I.P, and Sheet Pile construction method. Furthermore, the environmental costs of the S.C.W and C.I.P construction methods are quite similar. In the composite soil condition of deep excavation (as shown in Table 9), in the environmental cost calculation conducted by analyzing the environmental economic feasibility, as was carried out for the shallow excavation, when it comes to the total environmental costs expected in the construction stage of the installation condition for the earth-retaining wall, the H-Pile+Earth Plate construction method had the highest costs (KRW 346.6 million), and the environmental cost associated with ecotoxicity was the highest. For the other three construction methods, excluding the H-Pile+Earth Plate construction method, the highest environmental cost was associated with global warming.

Second, in the sandy soil condition of shallow excavation (as shown in Table 8), when it comes to the expected total environmental cost at the construction stage of the corresponding earth-retaining wall, the H-Pile+Earth Plate construction method had the largest cost (KRW 130.2 million), with the largest share of that cost due to ecotoxicity. Moreover, the three construction methods excluding H-Pile+Earth Plate had the largest environmental costs due to resource depletion and global warming, and it was found that the environmental costs of the C.I.P and S.C.W construction methods are similar. In the sandy soil condition of deep excavation (as shown in Table 9), when it comes to the total environmental cost expected in the construction stage of the earth-retaining wall installation condition, the total environmental cost of $\mathrm{H}$-Pile+Earth Plate was the highest (KRW 355.9 million), and the environmental cost for ecotoxicity was the highest. For the three construction methods, excluding H-Pile+Earth Plate, the environmental cost for global warming was the highest.

Third, in soft clay ground in shallow excavation (as shown in Table 8), the total environmental costs expected in the construction stage of the Sheet Pile installation condition were KRW 48.7 Million, and the total environmental costs in the shallow excavation and medium-sized Sheet Pile installation condition were twice as high as the total environmental costs in other soil conditions. The environmental costs due to global warming account for the largest share. In soft clay ground in deep excavation (as shown in Table 9), the total environmental cost of the Sheet Pile construction method was KRW 123.6 million, which is twice as high as the cost in other soil conditions in a deep and medium-sized excavation $(\mathrm{H}=15 \mathrm{~m}, 50 \times 50 \mathrm{~m})$, and the environmental cost associated with global warming was the highest.

\subsection{Relationship between Excavation Depth, Total Environmental Load, and Total Environmental Cost by Soil Condition}

As shown in Figure 6, the total environmental cost of the H-Pile+Earth Plate construction method was the highest in composite soil, and that cost was higher than the cost associated with the other three construction methods. Moreover, the deeper the excavation depth, the clearer the increase in total environmental cost. We confirmed that the total environmental costs of the C.I.P and S.C.W construction methods were similar, and this tendency remained the same when the excavation depth increased. The total environmental cost in sandy soil was similar to that in composite soil, but the cost in sandy soil was slightly greater. In soft clay soil, the total environmental cost of the Sheet Pile construction method increased as excavation depth increased, and the total environmental cost in soft clay soil was twice as high as that in other soil conditions. Furthermore, the assessments of environmental load and environmental cost were similar. 


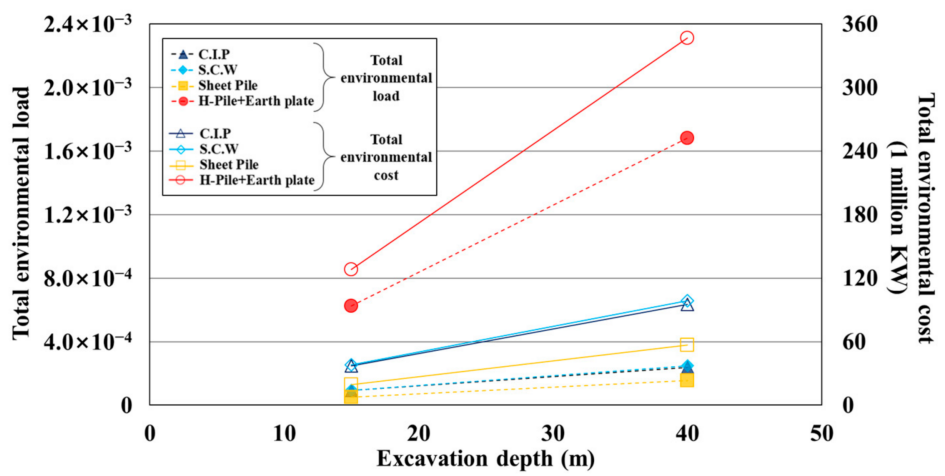

(a)

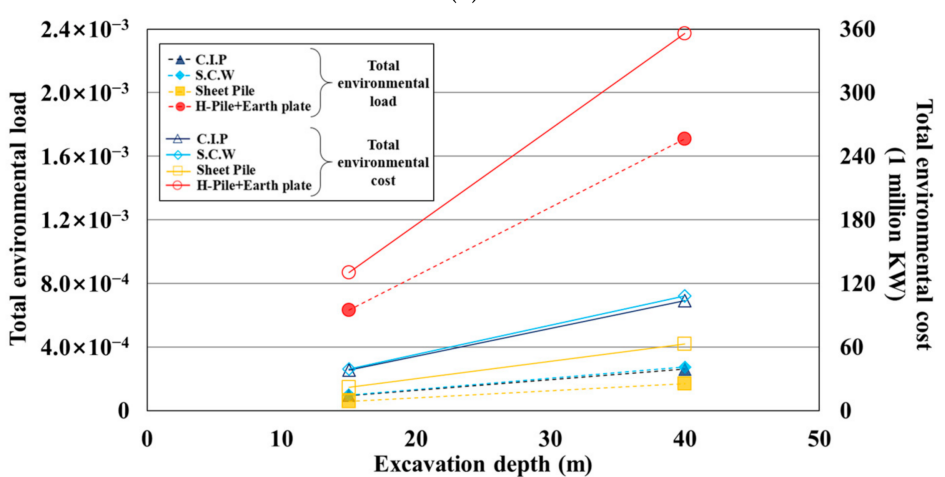

(b)

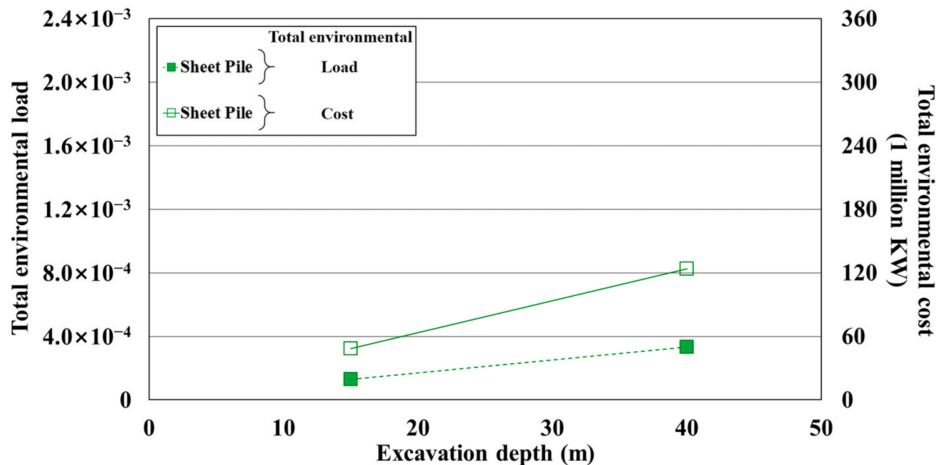

(c)

Figure 6. Relationship between total environmental load and total environmental cost by excavation depth and soil condition: (a) composite soil; (b) sandy soil; (c) soft clay soil.

\section{Conclusions}

This study evaluated the combination of excavation depth and soil condition in medium-sized excavation ground in order to examine the effect of construction methods on environmental economic feasibility for an earth-retaining wall during soil excavation. LCA analysis of the construction stage of the earth-retaining wall was conducted in consideration of eight environmental impact categories, the criteria for selecting the construction method for the earth-retaining wall considering the environmental costs of each construction method were reviewed, and the following conclusions were obtained as a result of this research:

1. If a calculation is conducted after calculating the environmental load by list analysis of the construction stage, this affects the selection of the construction method for the earth-retaining wall, so it is possible to select an optimal construction method for an earth-retaining wall considering stability and economic feasibility in various soil conditions via selection of a construction method that considers environmental loads in line with international trends. 
2. Evaluation of the stability of the earth-retaining wall revealed that the C.I.P construction method was the best in terms of stability in both composite soil and sandy soil in the case of a shallow excavation. In terms of stability in the case of deep excavation, the S.C.W construction method was the best in composite soil and the C.I.P construction method was the best in sandy soil. In soft clay soil, the deeper the excavation depth, the greater the safety factor.

3. Evaluation of the environmental load of construction methods for the earth-retaining wall revealed that the H-Pile+Earth Plate construction method had low economic feasibility compared to the other construction methods because the environmental load of the H-Pile+Earth Plate method increased due to an increase in ecotoxicity. Furthermore, at the same excavation depth, the environmental load characteristics had a greater effect on the selection of construction methods in sandy soil than in composite soil.

4. Evaluation of the environmental costs of the construction methods for the earthretaining wall revealed that the deeper the excavation depth, the greater the environmental cost. For a shallow excavation, in both composite and sandy soil, the H-Pile+Earth Plate construction method had low economic feasibility with the highest environmental cost, and the same is true for a deep excavation. In the case of soft clay soil, the environmental cost of the Sheet Pile construction method was higher than in other soil conditions, and the environmental cost was higher in sandy soil than in composite soil.

This study considered only the environmental effect in the determination of the retaining wall. Therefore, research should be conducted on the effect of various cost conditions on sustainability in order to be applied to the site.

Author Contributions: Conceptualization, Y.S., S.L. and J.-G.H.; methodology, J.-G.H. and G.H.; software, Y.S. and S.L.; validation, Y.S., J.-Y.L. and G.H.; formal analysis, Y.S., J.-G.H. and G.H.; investigation, S.L. and J.-Y.L.; resources, Y.S. and S.L.; data curation, J.-G.H. and G.H.; writingoriginal draft preparation, Y.S.; writing-review and editing, J.-G.H. and G.H.; visualization, J.-Y.L. and G.H.; supervision, J.-G.H.; project administration, S.L. All authors have read and agreed to the published version of the manuscript.

Funding: This research was supported by the MSIT (Ministry of Science and ICT), Korea, under the ITRC (Information Technology Research Center) support program (IITP-2020-2020-0-01655), the MSIT(NRF-2019R1A2C2088962) and the X-mind Corps program (2017H1D8A1030599) from the National Research Foundation (NRF) of Korea, the Human Resources Development (No.20204030200090) of the Korea Institute of Energy Technology Evaluation and Planning (KETEP) grant funded by the Korean government, and the Korea Agency for Infrastructure Technology Advancement funded by the Ministry of Land, Infrastructure and Transport of the Korean government (19SCIP- B108153-05).

Institutional Review Board Statement: Not applicable.

Informed Consent Statement: Not applicable.

Data Availability Statement: The data presented in this study are available on request to the corresponding author. The data are not publicly available as they form part of an ongoing study.

Conflicts of Interest: The authors declare no conflict of interest.

\section{References}

1. ISO. ISO 14040: 2006-Environmental Management, Life Cycle Assessment, Principles and Framework; International Organization for Standardization: Geneva, Switzerland, 2006.

2. ISO. ISO 14044: 2006-Environmental Management, Life Cycle Assessment, Requirement sand Guidelines; International Organization for Standardization: Geneva, Switzerland, 2006.

3. Guggemos, A.A.; Horvath, A. Comparison of Environmental Effects of Steel- and Concrete-Framed Buildings. J. Infrastruct. Syst. 2005, 11, 93-101. [CrossRef]

4. Keoleian, G.A.; Kendall, A.; Dettling, J.E.; Vanessa, M.S.; Richard, F.C.; Michael, D.L.; Victor, C.L. Life cycle modeling of concrete bridge design: Comparison of engineered cementitious composite link slabs and conventional steel expansion joints. J. Infrastruct. Syst. 2005, 11, 51-60. [CrossRef] 
5. Araújo, J.P.C.; Oliveira, J.R.M.; Silva, H.M.R.D. The importance of the use phase on the LCA of environmentally friendly solutions for asphalt road pavements. Transp. Res. Part D Transp. Environ. 2014, 32, 97-110. [CrossRef]

6. Society of Environmental Toxicology and Chemistry (SETAC). Guidelines for Life-Cycle Assessment: A "Code of Practice"; SETAC Publications: Pensacola, FL, USA, 1993.

7. China National Institute of Standardization. GB/T 24040-2008 Environmental Management-Life Cycle Assessment-Principle and Framework; Standard Press of China: Beijing, China, 2008.

8. Hui, M.; Zhigang, Z.; Xia, Z.; Shuang, W. A Comparative Life Cycle Assessment (LCA) of Warm Mix Asphalt (WMA) and Hot Mix Asphalt (HMA) Pavement: A Case Study in China. Adv. Civ. Eng. 2019, 19, 9391857.

9. Guggemos, A.A. Environmental Impacts of On-Site Construction Processes: Focus on Structural Frames. Ph.D. Thesis, University of California, Berkeley, CA, USA, 2003.

10. Guggemos, A.A.; Horvath, A. Decision-support tool for assessing the environmental effects of constructing commercial buildings. J. Arch. Eng. 2006, 12, 187-195. [CrossRef]

11. Lee, J.H. A Study on GHG Emissions and Mitigation Potentials of the Industrial Sector in Korea. Master's Thesis, Keimyung University, Daegu, Korea, 2010.

12. Mao, C.; Shen, Q.; Shen, L.; Tang, L. Comparative study of greenhouse gas emissions between off-site prefabrication and conventional construction methods: Two case studies of residential projects. Energy Build. 2013, 66, 165-176. [CrossRef]

13. Hong, J.; Shen, G.Q.; Feng, Y.; Lau, W.S.T.; Mao, C. Greenhouse gas emissions during the construction phase of a building: A case study in China. J. Clean. Prod. 2015, 103, 249-259. [CrossRef]

14. Luo, W.; Sandanayake, M.; Zhang, G. Direct and indirect carbon emissions in foundation construction-Two case studies of driven precast and cast-in-situ piles. J. Clean. Prod. 2019, 211, 1517-1526. [CrossRef]

15. Frey, H.C.; Rasdorf, W.; Lewis, P. Comprehensive field study of fuel use and emissions of nonroad diesel construction equipment. Transp. Res. Rec. J. Transp. Res. Board 2010, 2158, 69-76. [CrossRef]

16. Lewis, P. Estimating Fuel Use and Emission Rates of Nonroad Diesel Construction Equipment Performing Representative Duty Cycles. Ph.D. Thesis, North Carolina State University, Raleigh, NC, USA, 2009.

17. Lewis, P.; Frey, H.C.; Rasdorf, W. Development and use of emissions inventories for construction vehicles. Transp. Res. Rec. J. Transp. Res. Board 2009, 2123, 46-53. [CrossRef]

18. Junnila, S.; Horvath, A.; Guggemos, A.A. Life-Cycle Assessment of Office Buildings in Europe and the United States. J. Infrastruct. Syst. 2006, 12, 10-17. [CrossRef]

19. Sandanayake, M.; Zhang, G.; Setunge, S. Environmental emissions at foundation construction stage of buildings-Two case studies. Build. Environ. 2016, 95, 189-198. [CrossRef]

20. Zhang, G.; Sandanayake, M.; Setunge, S.; Li, C.; Fang, J. Selection of emission factor standards for estimating emissions from diesel construction equipment in building construction in the Australian context. J. Environ. Manag. 2017, 187, 527-536. [CrossRef]

21. Sandanayake, M.; Zhang, G.; Setunge, S.; Luo, W. Estimation and comparison of environmental emissions and impacts at foundation and structure construction stages of a building-A case study. J. Clean. Prod. 2017, 151, 319-329. [CrossRef]

22. Sandanayake, M.; Zhang, G.; Setunge, S. A comparative method of air emission impact assessment for building construction activities. Environ. Impact Assess. Rev. 2018, 68, 1-9. [CrossRef]

23. Santero, N.J. Pavements and the Environment: A Life-Cycle Assessment Approach. Ph.D. Thesis, University of California Berkeley, Berkeley, CA, USA, 2009. Unpublished work.

24. Bjarne, S.; Jeppe, C.D. $\mathrm{CO}_{2}$ emission reduction by exploitation of rolling resistance modelling of pavements. Procedia Soc. Behav. Sci. 2012, 48, 311-320.

25. Shang, C.; Zhang, Z.; Li, X. Research on energy consumption and emission of life cycle of expressway. J. Highway Transp. Res. Dev. 2010, 27, 149-154.

26. Ministry of Land, Infrastructure and Transport of Republic of Korea. Environmental Load Reduction Type LCA (Life Cycle Assessment) Based Design and Construction Technology Development; Construction \& Transportation R\&D Report; Ministry of Land, Infrastructure and Transport: Sejong, Korea, 2017.

27. Lee, Y.K.; Han, J.G.; Kwon, S.H. A Study on the Evaluation of Environmental Load Based on LCA Using BIM-Focused on the Case of NATM Tunnel. J. Korean Soc. Civil Eng. 2018, 38, 477-485.

28. Häkkinen, T.; Mäkelä, K. Environmental Adaption of Concrete: Environmental Impact of Concrete and Asphalt Pavements; VTT Technical Research Centre of Finland: Espoo, Finland, 1996.

29. Han, I.X.; Zhow, W.; Tang, L.C.M. Model-based life cycle cost and assessment tool for sustainable building design decision. In Proceedings of the 4th International Conference on Construction Engineering and Project Management (ICCEPM-20011), Sydney, Australia, 16-18 February 2011.

30. Kwon, S.H. Development of Assessment Model for Environmental Economics of Construction Projects. Ph.D. Thesis, Chung-Ang University, Seoul, Korea, 2008.

31. Bae, C.H. A Study on the Selection of Retaining Wall System for the Underground. Master's Thesis, Chonnam National University, Gwangju, Korea, 2010.

32. Han, J.G.; Lee, J.Y. Case Study on AHP Technique Application for the Reinforcing Method Selection on a Cut-Slope. J. Korean Geotech. Soc. 2008, 24, 81-88. 
33. Lee, H.C.; Woo, S.K.; Kim, O.K. Development of Decision Making Model for Selecting the Soft Foundation Improvement Method Using AHP technique. J. Korean Soc. Civ. Eng. 2007, 27, 499-506.

34. Lee, C.H.; Jeong, K.C. An Analytic Hierarchy Process based Decision Support System for Selecting Foundation Practice. Korean J. Constr. Eng. Manag. 2012, 13, 129-139. [CrossRef]

35. Pan, N.F. Fuzzy AHP approach for selecting the suitable bridge construction method. Autom. Constr. 2008, 17, 958-965. [CrossRef]

36. Ebrahimian, A.; Ardeshir, A.; Radb, I.Z.; Ghodsypour, S.H. Urban stormwater construction method selection using a hybrid multi-criteria approach. Autom. Constr. 2015, 58, 118-128. [CrossRef]

37. Shen, L.; Yan, H.; Fan, H.; Wu, Y.; Zhang, Y. An integrated system of text mining technique and case-based reasoning (TM-CBR) for supporting green building design. Build. Environ. 2017, 124, 388-401. [CrossRef]

38. Lorenz, T.; Jost, A. Towards an orientation framework in multi-paradigm modelling: Aligning purpose, object and methodology in System Dynamics, Agent-based Modeling and Discrete-Event-Simulation. In Proceedings of the 24th International Conference of the System Dynamics Society, Nijmegen, The Netherlands, 23-27 July 2006; pp. 2134-2151.

39. Tsai, W.H.; Lin, S.J.; Lee, Y.F.; Chang, Y.C.; Hsu, J.L. Construction method selection for green building projects to improve environmental sustainability by using an MCDM approach. J. Environ. Plan. Manag. 2013, 56, 1487-1510. [CrossRef]

40. Kim, J.Y.; Park, W.Y.; Kang, K.I. A Study on the Selection System of Retaining Wall Methods Using Neural Network. J. Archit. Inst. Korea Struct. Constr. 2002, 18, 69-76.

41. Yau, N.J.; Yang, J.B. Applying case-based reasoning technique to retaining wall selection. Autom. Constr. 1998, 7, $271-283$. [CrossRef]

42. Park, J.K.; Jun, S.K.; Kim, Y.K.; Heo, E.N. A study on the improvement in decision making analysis for the selection of tunnel construction method. J. Korean Tunnel Undergr. Space Assoc. 2002, 4, 261-276.

43. Ministry of Land, Infrastructure and Transport. KDS 2130 00: 2016, Korean Design Standard; Ministry of Land, Infrastructure and Transport: Sejong, Korea, 2016.

44. Caspe, M.S. Surface settlement adjacent to braced open cut. J. Soil Mech. Found. Div. 1966, 92, 51-59. [CrossRef]

45. Bowles, J.E. Foundation Design and Analysis, 4th ed.; McGraw-Hill Book Company Limited: Maidenhead, UK, 1988 ; pp. 658-661.

46. Ministry of Land, Infrastructure and Transport of Republic of Korea. Standard of Construction Estimate; Ministry of Land, Infrastructure and Transport: Sejong, Korea, 2017. 